\title{
State of the inter-farm irrigation canal: in the case of Khorezm province, Uzbekistan
}

\author{
Bakhtiyar Matyakubov ${ }^{1, *}$, Giyosiddin Goziev², and Umida Makhmudova ${ }^{1}$ \\ ${ }^{1}$ Tashkent Institute of Irrigation and Agricultural Mechanization Engineers, Kari Niyazi str., 39, \\ Tashkent, Uzbekistan, 100000 \\ ${ }^{2}$ Ministry of Innovative Development of the Republic of Uzbekistan, 7, University str., Tashkent, \\ 100174, Uzbekistan
}

\begin{abstract}
The article describes the monitoring and calculations for the repair and maintenance of the "Sarchali" canal. At present, it is reported that the value of available water resources is high due to the annual decrease in irrigation water. Effective use of irrigation canals in the supply of water to the Water Consumers Association is one of the urgent tasks. During the field surveys, the current condition of the canal and the technical condition of the hydraulic structures in it were fully monitored, and as a result of many years of field data, the operation of the canal was analyzed. From the scientific point of view, the conclusion was made on the repair of the canal and its hydraulic structures or the construction of new hydraulic structures. The current condition of the Sarchali canal along the entire length of the canal was studied in the field, and based on the results of the study, it was determined to repair the canal or build new facilities.
\end{abstract}

\section{Introduction}

In order to save water resources in irrigated agriculture, it is necessary to ensure the efficient operation of irrigation networks in the efficient use of available water resources, the introduction of water-efficient irrigation technologies [1, 5-7].

At the same time, it is planned to increase the share of concrete-lined canals in the modernization of irrigation systems, modernization of control and measuring equipment and notification systems in hydraulic structures, the introduction of digital technologies in hydrological posts $[2,3,10]$.

In the effective use of irrigation networks, at a time when water shortages are growing, the repair and rehabilitation of canals, ensuring the working condition of hydraulic structures is also of great importance $[4,8,9]$.

In Khorezm region in 2020, $621 \mathrm{~km}$ of inter-farm and 6,669 $\mathrm{km}$ of internal irrigation canals were cleaned, 131 hydraulic structures, 110 hydroposts were repaired and new ones were built to increase the water use ratio [7, 17].

As a result of the reconstruction of $52.9 \mathrm{~km}$ of irrigation networks, 8 hydraulic structures and 6 flood facilities in the region, the reclamation of 12.2 thousand hectares of

\footnotetext{
* Corresponding author: b.matyakubov@tiiame.uz
} 
irrigated land has improved. The region plans to redevelop 12.5 thousand hectares of decommissioned land in 2021 through the repair of irrigation networks and the introduction of water-saving technologies [3, 11].

Many scientists have focused on the rational use of water resources and ensuring the proper functioning of irrigation networks in times of water shortage, the use of collectorditch mineralization in irrigation through biological treatment and the use of irrigation water-saving methods in the field. including: Avlakulov M., Balla D., Omar M., Maassen S., Hamidov A., Khamidov M., Isabaev K., Matyakubov B., Begmatov I. and others [4-16].

Using the information provided by the above scientists, in 2020 in Khorezm region on the introduction of water-saving technologies was carried out construction work on 1,100 hectares of 87 farms $[17,20]$.

A number of scientists have studied the waste of water in irrigation networks in the country, as well as monitoring and repair of hydraulic structures in the canal, construction of new and application of water-saving irrigation technologies in the field, optimization of hydraulic parameters of canals, assessment and improvement of reclamation of irrigated lands, these are Bazarov D., Yangiev A., Isabaev K., Matyakubov B. and others [8-16].

Today, one of the most pressing issues is the prevention of serious problems in the irrigation of agricultural crops, the study of the state of irrigation networks and their repair. Increasing the efficiency of irrigation systems and irrigation networks is of great importance in saving irrigation water [17-19, 21-23].

Taking into account the views of the above scientists, it was found that currently no scientific research has been conducted to reduce water wastage in the canal through the study, repair and construction of the Sarchali canal and its hydraulic structures in Khiva, Khorezm region.

The issue of development of science and education in the field of water management is of special importance, and the construction and reconstruction of irrigation and land reclamation facilities need to be scientifically substantiated.

\section{General information}

Accurate data on repair and restoration along the length of the canal, areas where it is necessary to make concrete or build a new one, as well as control and design of hydraulic structures to ensure the effective operation of the canal by monitoring were studied in the analytical field.

Monitoring of the condition of hydraulic structures and repair or construction of new ones to ensure the required level of water in the Sarchali canal was identified. According to the results of technical and economic calculations and observations, the canal is $3800 \mathrm{~m}$. Reconstruction of the existing part of the canal from PK $0+00$ to PK $38+00$ was determined [17].

"Sarchali" Canal The canal was commissioned in 1938 and supplies water to 1600 hectares of land in Kenik-Polvan SIU in Khiva district. Normal operation of the canal is 2.0 $\mathrm{m}^{3} / \mathrm{sec}$, total length is $7.3 \mathrm{~km}$, of which $3,016 \mathrm{~km}$ (from PK $0+00$ to PK $30+16$ ) are covered with concrete [17].

The Sarchali canal receives water from the Ak-yab canal in a flowing state (Fig. 1). In some parts of the concrete part of the canal, the concrete part has become unusable. 


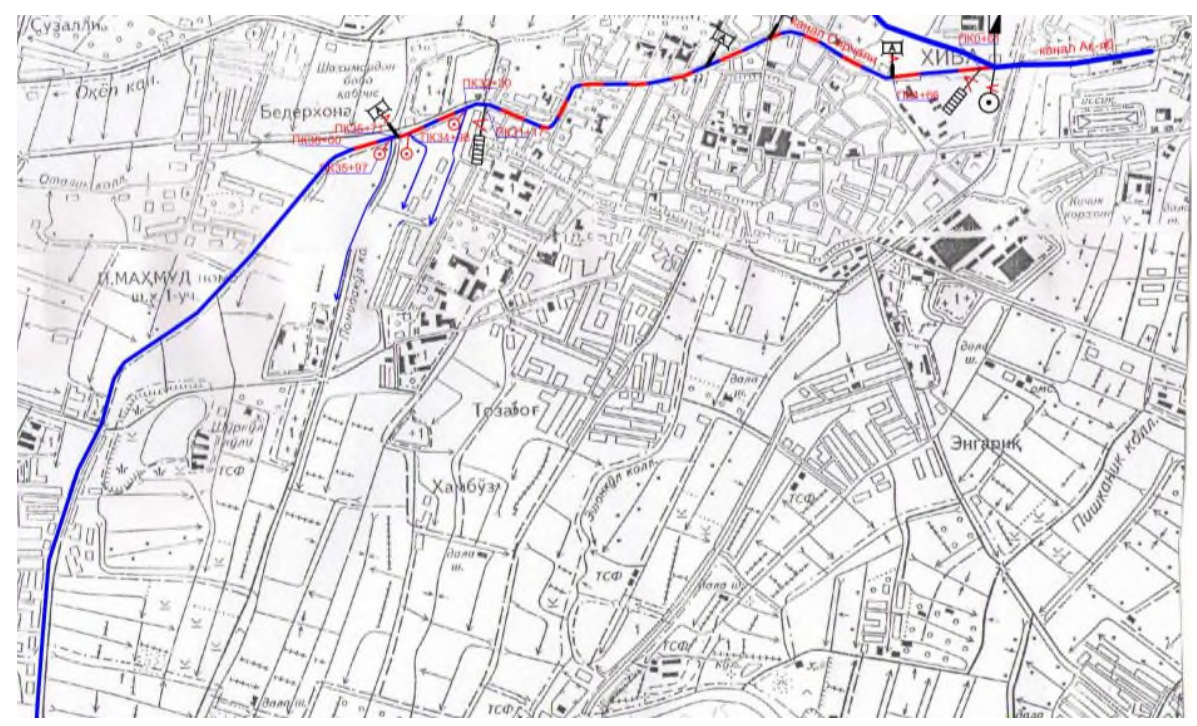

Fig. 1. Map of the study area.

The hydraulic structures in the canal are outdated and in need of repair. Hydroposts at PK $0+61$ and PK $31+17$, reinforced concrete bridges at PK $4+63$ and PK35+74 are in need of repair.

There is no water intake in the ditch at PK $32+30$. PK $34+98$, PK35 +74 water intake pipes are obsolete, there is no metal equipment.

In order to improve the demand for water of agricultural crops in the "Sarchali" canal system, increase the efficiency of water use and improve the operating conditions of the canal, it is planned to implement the following measures:

1. Cleaning the canal from mud $-3.8 \mathrm{~km}$

2. Reconstruction of the canal $-0.784 \mathrm{~km}$

3. Repair of the concrete part of the canal $-0.229 \mathrm{~km}$

4. Hydraulic structures:

a. Newly built:

- Water intake facilities - 3 pcs

b. Reconstructed:

- main building - 1 pcs

- car bridge - 2 pcs

\section{Technical solution}

It was observed that irrigation water was wasted due to the technical condition and faults of hydraulic structures. In addition, the work to be done to eliminate the existing problems was identified.

The technical condition of the Sarchali canal and the non-functioning of existing hydraulic structures in the water distribution, the lack of water intake facilities, the need for repair of water metering facilities (hydroposts) were identified. It was noted that it is expedient to use modern irrigation technologies to prevent uneven distribution of water along the length of the canal when irrigating the canal.

The main focus of scientific monitoring is the need to develop and implement proposals and recommendations for the repair, rehabilitation of irrigation canals and the construction of new hydraulic structures $[18,19]$. 
The main purpose of this proposal and recommendation is to monitor, study the technical condition of the canal and its existing hydraulic structures, repair or build a new one to keep it in working condition.

The following indicators were taken into account when reconstructing or constructing new hydraulic structures:

- supply of water according to crop demand;

- value of water use coefficient;

- changes in the water permeability of the canal;

- Decision of the canal management board in the Water Consumers Association and others.

Based on the above requirements, 8 hydraulic structures were identified in the Sarchali canal: 3 new constructions and 3 reconstructions [17].

In order to organize the work on the set goals and objectives, the following was identified:

- monitoring the technical condition of the channel;

- Monitoring the operation and technical condition of hydraulic structures in the canal;

- Presence of a double protection zone in the channel;

- Providing and implementing recommendations for the repair or construction of new hydraulic structures in the canal.

\section{Materials and methods}

The method of monitoring the technical condition of the canal and its hydraulic structures was used. Normative and legal documents on ensuring the safety of hydraulic structures, as well as methods of analyzing statistical data in the process of determining and monitoring the safety of the canal and its hydraulic structures were used [20,21].

The survey was carried out on the basis of surveys, taking into account the actual condition of the canal and its hydraulic structures, depending on the function, level of perfection, design features, operating conditions and special requirements for safety.

\section{Results and discussion}

Due to the existing problems in the monitoring, the information in the Project Passport at the time of construction of the primary channel will be reviewed and suggestions and recommendations will be made on this basis.

The Sarchali canal was built and put into operation in 1938. Currently, the condition of the canal is not working at the required level, and the need for repair of hydraulic structures in the canal is one of the main problems due to the high level of water leakage in the canal and the supply of the required amount of crops.

The need for reconstruction of the Sarchali canal and its hydraulic structures, or the construction of a new one, was determined by the length of the canal and the condition of the canal.

According to the observations made in the Sarchali canal, it is difficult to control the water in the canal, and the water supply of the crops has deteriorated, and the crops at the end of the canal do not supply the required amount of water to the cultivated areas.

Based on this, the technical and economic indicators of the canal were calculated (Table $1)$. 
Table 1. Technical and economic indicators.

\begin{tabular}{|c|c|c|c|c|}
\hline \multirow{2}{*}{ \# } & \multirow{2}{*}{ Indicators } & \multirow{2}{*}{$\begin{array}{c}\text { Unit of } \\
\text { measurement }\end{array}$} & \multicolumn{2}{|c|}{ Quantity } \\
\hline & & & available & project \\
\hline 1 & Irrigated land area: total & ha & 1650 & 1650 \\
\hline \multirow{3}{*}{2} & Repair duct length: & $\mathrm{km}$ & 3.8 & 3.8 \\
\hline & $\begin{array}{c}\text { - existing concrete } \\
\text { coating }\end{array}$ & $\mathrm{km}$ & 3.016 & 3.016 \\
\hline & - new concrete coating & $\mathrm{km}$ & - & 0.784 \\
\hline 3 & Canal water consumption & $\mathrm{m}^{3} / \mathrm{sec}$ & - & 2.0 \\
\hline 4 & Irrigation hydromodule & $1 / \mathrm{sec}$ ha & - & 0.74 \\
\hline 5 & Canal efficiency & & - & 0.95 \\
\hline 6 & $\begin{array}{c}\text { Constructions of Hydraulic } \\
\text { engineering }\end{array}$ & pcs & - & 8 \\
\hline \multirow{3}{*}{7} & Reconstructed: & pes & & 1 \\
\hline & $\begin{array}{c}\text { - the bridge of main } \\
\text { construction }\end{array}$ & pcs & - & 2 \\
\hline & - hydroposts & pcs & - & 2 \\
\hline \multirow{2}{*}{8} & Newly built: & & & \\
\hline & - water intake facility & pes & - & 3 \\
\hline \multirow{9}{*}{9} & Basic work volumes: & & & \\
\hline & - dig & $\mathrm{m}^{3}$ & - & 6775 \\
\hline & - shear & $\mathrm{m}^{3}$ & - & 125 \\
\hline & -reburial and lifting & $\mathrm{m}^{3}$ & - & 368 \\
\hline & - precast reinforced concrete & $\mathrm{m}^{3}$ & - & 7.2 \\
\hline & $\begin{array}{l}\text { - solid concrete and } \\
\text { reinforced concrete }\end{array}$ & $\mathrm{m}^{3}$ & - & 776.84 \\
\hline & $\begin{array}{l}\text { - Reinforcement for solid } \\
\text { reinforced concrete }\end{array}$ & $\mathrm{m}^{3}$ & - & 0.783 \\
\hline & $\begin{array}{c}\text {-metallic equipment and } \\
\text { fixtures-metallic equipment } \\
\text { and fixtures }\end{array}$ & $\mathrm{m}^{3}$ & - & 0.99 \\
\hline & - stone & $\mathrm{m}^{3}$ & - & 9.9 \\
\hline 10 & $\begin{array}{l}\text { Construction period } \\
\text { (autumn-winter period) }\end{array}$ & month & - & 8 \\
\hline
\end{tabular}

In order to prevent the above-mentioned problems, information on the technical and economic performance of the Sarchali canal is of great importance, including:

1. Service area: 1,650 ha.

2. The required length of the canal to be cleared of mud is $3,800 \mathrm{~m}$.

3. The length of the canal to be re-concreted is $784 \mathrm{~m}$.

4. The length of the repair of the concrete part of the canal is $229 \mathrm{~m}$

5. Newly constructed hydraulic structures, including water intake facilities - 3 pcs.

6. Reconstructed hydraulic structures: 1 main structure and 2 road bridges.

The decrease in the water permeability of the canal is mainly due to turbid sediments and fire in the canal (Fig. 2). 

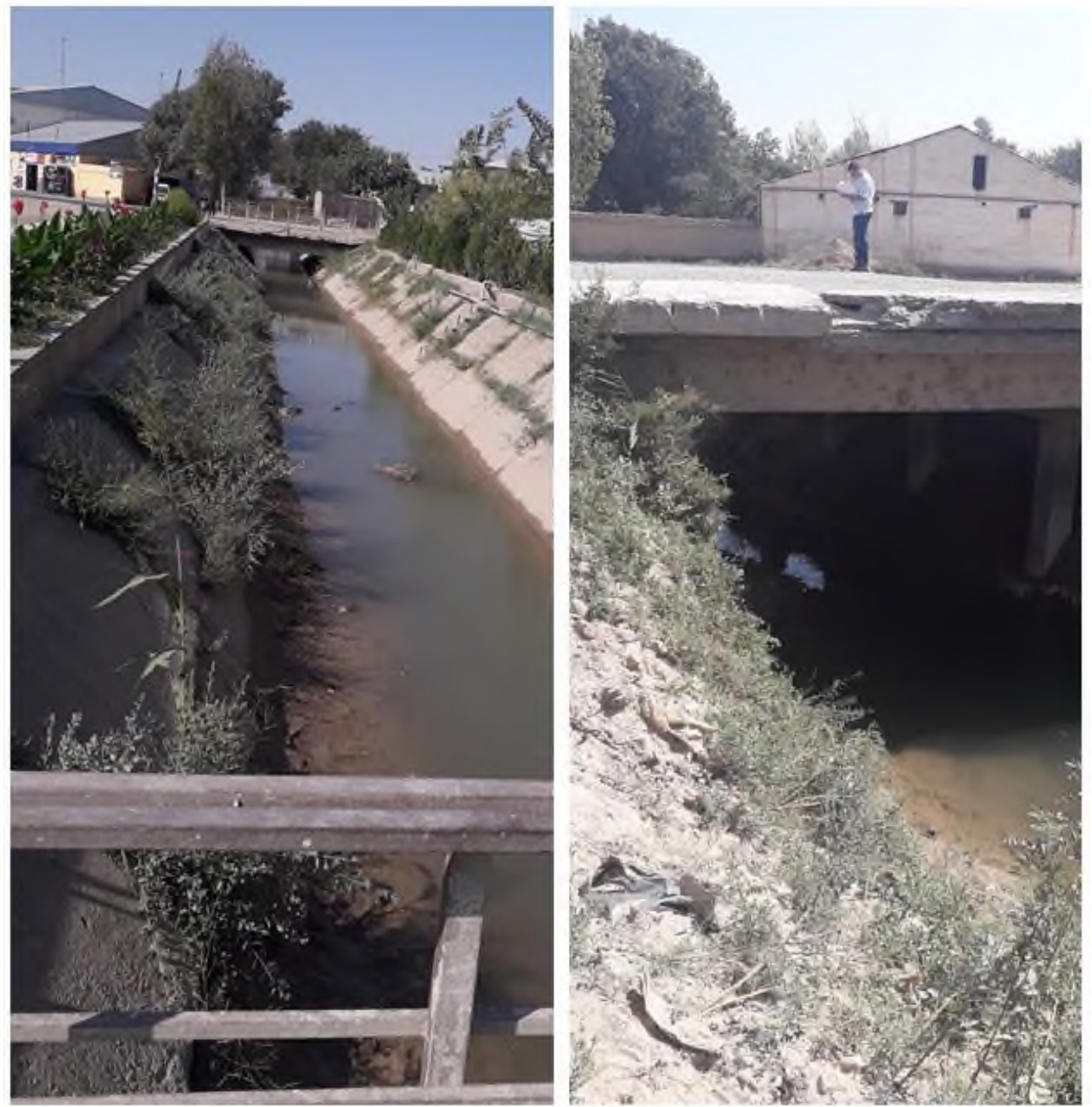

Fig. 2. General view of "Sarchali" canal.

According to the results of the monitoring, in the Sarchali canal system it is important to improve the demand for water of agricultural crops, increase water use efficiency, improve the conditions of canal operation and beautification of the canal area and further use of digitization technology.

The estimated water consumption of the canals receiving water from the Sarchali canal was determined depending on the irrigated crop area, the maximum ordinate of the hydromodule and the efficiency of the canal.

The efficiency of domestic canals was 0.72 according to the calculated measurements (Table 2). 
Table 2. Calculation of water consumption of canals receiving water from the "Sirchali" canal.

\begin{tabular}{|c|c|c|c|c|c|}
\hline $\begin{array}{c}\text { On the } \\
\text { canal } \\
\text { of streams } \\
\text { location } \\
\text { range }\end{array}$ & $\begin{array}{c}\text { Irrigated } \\
\text { land } \\
\text { area, ha }\end{array}$ & $\begin{array}{c}\text { Hydromodule } \\
\text { ordinate } \\
\mathbf{1} / \mathbf{s} / \mathbf{h a}\end{array}$ & $\begin{array}{c}\text { Net water } \\
\text { consumption } \\
\text { of streams } \\
\mathbf{m}^{3} / \mathbf{s e c}\end{array}$ & $\begin{array}{c}\text { Efficiency } \\
\text { of streams }\end{array}$ & $\begin{array}{c}\text { Plenary } \\
\text { water } \\
\text { consumption } \\
\text { of streams } \\
\mathbf{m}^{3} / \mathbf{s e c}\end{array}$ \\
\hline $\begin{array}{c}\text { PK0+ 00 } \\
\text { PK38+00 }\end{array}$ & 115 & 0.74 & 0.085 & 0.72 & 0.118 \\
\hline $\begin{array}{c}\text { After PK38 } \\
\text { + 00 }\end{array}$ & 1535 & 0.74 & 1.136 & 0.72 & 1.578 \\
\hline Total: & & & & & $\mathbf{1 . 6 9 6}$ \\
\hline
\end{tabular}

In determining the plenary water consumption of the canal, it is determined taking into account the amount of water lost in the canal or the efficiency.

According to the calculations, the filtration loss per $1 \mathrm{~km}$ of the concrete-covered part of the channel from PK $0+00$ to PK $38+00$ is $0.008 \mathrm{~m}^{3} / \mathrm{s}$. The total water loss through the canal was $0.065 \mathrm{~m}^{3} / \mathrm{s}$.

During the execution and organization of construction works, sludge removal works are carried out using a hydraulic excavator with a bucket capacity of $0.5 \mathrm{~m} 3$. Muddy soils are loaded onto dump trucks using an excavator (Table 3).

Table 3. Volume of construction works.

\begin{tabular}{|c|c|c|c|c|c|c|c|}
\hline$\#$ & $\begin{array}{c}\text { Types of } \\
\text { constructions }\end{array}$ & $\begin{array}{c}\text { Measurement } \\
\text { unit }\end{array}$ & Quantity & $\begin{array}{l}\text { Dig, } \\
\mathbf{m}^{3}\end{array}$ & $\begin{array}{c}\text { Shear, } \\
\mathbf{m}^{3}\end{array}$ & $\underset{\mathrm{m}^{3}}{\text { Lifting }}$ & $\begin{array}{c}\text { Precast } \\
\text { reinforced } \\
\text { concrete } \\
\mathbf{m}^{3}\end{array}$ \\
\hline 1 & $\begin{array}{l}\text { Cleaning the canal } \\
\text { from mud }\end{array}$ & $\mathrm{km}$ & 3.8 & 6,559 & 125 & 176 & \\
\hline 2 & $\begin{array}{l}\text { Concreting the canal } \\
\text { again }\end{array}$ & $\mathrm{km}$ & 0.784 & & & & \\
\hline 3 & $\begin{array}{l}\text { Repair of the existing } \\
\text { concrete part of the } \\
\text { canal }\end{array}$ & $\mathrm{km}$ & 0.229 & & & & \\
\hline 4 & $\begin{array}{l}\text { Repair of the main } \\
\text { water intake facility }\end{array}$ & pcs & 1 & & & & \\
\hline 5 & Hydropost repair & pcs & 2 & & & & \\
\hline 6 & $\begin{array}{c}\text { Repair of car bridge on } \\
\text { PK } 4+66\end{array}$ & pcs & 1 & & & & \\
\hline 7 & $\begin{array}{c}\text { PK35 + } 71 \text { car bridge } \\
\text { repair }\end{array}$ & pcs & 1 & & & & \\
\hline 8 & $\begin{array}{c}\text { Construction of water } \\
\text { intake facilities }\end{array}$ & pcs & 3 & 216 & & 192 & 7.2 \\
\hline & Total & & & 6,775 & 125 & 368 & 7.2 \\
\hline
\end{tabular}

Solid concrete preparation works are carried out at the construction site using a concrete mixing machine.

Transportation of the concrete mix is carried out using 5-ton dump trucks. The concrete mix is delivered to the construction joints using a truck crane in buckets with a capacity of $0.8 \mathrm{~m} 3$. The concrete mix is compacted using electric vibrators.

Prefabricated reinforced concrete structures are also assembled by truck crane. In the construction of hydraulic structures, traffic will use existing asphalt and dirt roads along the canals. 
Prior to construction, all engineering and communication networks at the intersection of the canal must be carried out in coordination with the relevant enterprises and with the participation of specialists.

At the beginning of the irrigation season, it is required to check the readiness of irrigation networks for water intake, distribution through canals and individual farms.

Timely and accurate water metering plan in irrigation networks is the basis for water distribution and rational use of water resources. To this end, it is important to carry out repair and restoration work on irrigation networks.

\section{Conclusions}

Based on the observations made to ensure that the canal and its hydraulic structures operate at the required level and supply the required amount of water to the crop, the following conclusions can be drawn:

1. Take measures to exploit the 'Sirchali' canal:

a) daily irrigation;

b) strict adherence to irrigation and saline washing standards;

c) minimization of water supply points to water consumers and farms, water accounting and control;

g) to prevent water from leaking between the barriers in the structures;

d) to prevent turbidity in the canal and the growth of vegetation in the canal.

2. Monitoring the technical condition of the canal and its structures and repairing the required areas.

3. Development and implementation of an action plan for the repair of the length of the canal and hydraulic structures in it.

4. Economic study of the technical condition of hydraulic structures in the canal, the choice of the optimal option.

5. Carrying out engineering works on modernization of the canal and its hydraulic structures.

\section{References}

1. N. Teshaev, B. Mamadaliyev, A. Ibragimov, S. Khasanov, InterCarto. InterGIS, 26(3), 324-333 (2020)

2. R. A. Kulmatov, S. A. Adilov, S. Khasanov, IOP Conf. Ser.: Earth Environ. Sci., 614(1), 012149 (2020)

3. A. Jumanov, S. Khasanov, A. Tabayev, G. Goziev, U. Uzbekov, E. Malikov, IOP Conf. Ser.: Earth Environ. Sci., 614(1), 012150 (2020)

4. M. Avlakulov, B. Matyakubov, K. Isabaev, S. Azizov, E. Malikov, Annals of the Romanian Society for Cell Biology, 25(1), 4538-4544 (2021)

5. D. Balla, M. Omar, S. Maassen, A. Hamidov, M. Khamidov, Environ. Sci. Eng. (Subseries: Environmental Science), 202979, 423-440 (2014)

6. B. Matyakubov, I. Begmatov, I. Raimova, G. Teplova, IOP Conf. Ser.: Mat. Sci. Eng., 883(1), 012050 (2020)

7. B. Matyakubov, International Water and Irrigation, 23(3), 26-27 (2003)

8. B. Sh. Matyakubov, Z. J. Mamatkulov, R. K. Oymatov, U. N. Komilov, G. E. Eshchanova, InterCarto, InterGIS, 26, 229-239 (2020) 
9. B. Matyakubov, K. Isabaev, D. Yulchiyev, S. Azizov, Journal of Critical Reviews, 7(5), $376-379(2020)$

10. B. Matyakubov, I. Begmatov, A. Mamataliev, S. Botirov, M. Khayitova, Journal of Critical Reviews, 7(5), 417 - 421 (2020)

11. M. Khamidov, B. Matyakubov, K. Isabaev, Journal of Critical Reviews, 7(4), 347-353 (2020)

12. M. Khamidov, K. Khamraev, SH. Azizov, G. Akhmedjanova, Journal of Critical Reviews, 7(1), 499-509 (2020)

13. S. Isaev, I. Begmatov, G. Goziev, S. Khasanov, IOP Conf. Ser.: Mater. Sci. Eng., 883(1), 012080 (2020)

14. M. R. Bakiev, A. A. Yangiev, O. A. Muratov, Magazine Architecture designing building, 4, 33-36 (2016)

15. N. Rakhmatov, D. Nazaraliev, F. Artykbekova, F. Uljaev, M. Sapaeva, O. Jumanov, IOP Conf. Ser.: Mater. Sci. Eng., 883(1), 012009 (2020)

16. O. B. Imamnazarov, M. M. Pulatova, M. S. Khayitova, SH. N. Azizov, E. N. Malikov, K. M. Qurbonov, Journal of Critical Reviews, 7(12), 924-927 (2020)

17. Working project: "Reconstruction of Sirchali canal with PK $0+00$ in PK $38+00$ in the city of Khiva Khorezmskoy oblast, Republic of Uzbekistan”, Urgench, 1, 23 (2020)

18. R. Kulmatov, A. Taylakov, S. Khasanov, Environ. Sci. Pollut. Res., 28(10), $12245-$ 12255 (2021)

19. I. Aslanov, S. Khasanov, Y. Khudaybergenov, M. Groll, Ch. Opp, F. Li, E. Ramirez Del-Valle, E3S Web Conf., 227, 02005 (2021)

20. S. Isaev, S. Khasanov, Y. Ashirov, T. Karabaeva, A. Gofirov, E3S Web Conf., 244, 02012 (2021)

21. S. Isaev, S. Khasanov, Y. Ashirov, A. Gofirov, T. Karabaeva, E3S Web Conf., 244, 02047 (2021)

22. Z. Mamatkulov, E. Safarov, R. Oymatov, I. Abdurahmanov, M. Rajapbaev, E3S Web Conf., 227, 03001 (2021)

23. K. Khakimova, I. Musaev, A. Khamraliev, E3S Web Conf., 227, 02003 (2021) 